\title{
RETRACTION
}

doi:10.1038/nature09030

\section{Transient FTY720 treatment promotes immune-mediated clearance of a chronic viral infection}

Mary Premenko-Lanier, Nelson B. Moseley, Sarah T. Pruett, Pablo A. Romagnoli \& John D. Altman

\section{Nature 454, 894-898 (2008)}

The authors wish to retract this Letter on the grounds that they have been unable to repeat key observations of the paper. Using currently available stocks of virus (LCMV clone 13) and drug (FTY720), they no longer observe that transient drug treatment of infected mice leads to immune-mediated clearance of virus. Although the authors will continue to investigate the matter, seeking to identify parameters that enable them to repeat the results they reported, they request that Nature retract the paper and regret any adverse consequences that may have resulted from the paper's publication. 